\title{
Hazards in Milling
}

Danuse Madlova ${ }^{1}$, Vlastislav Gebhart ${ }^{2}$

${ }^{1}$ Faculty of Production Technology and Management, J. E. Purkyne University in Usti nad Labem. Pasteurova 3334/7, 40001 Usti nad Labem. Czech Republic. E-mail: madlova@fvtm.ujep.cz

${ }^{2}$ OSVČ Gebhart. Skrivan 78, 27021 Pavlikov. Czech Republic. E-mail: gebhart.vl@seznam.cz

This paper is focused on hazards in milling processes. It continues in occupational health and safety in turning. Safety rules are based on general rules and specific ones which relate to milling. It is necessary to formulate hazard and safety rules more precisely for specific production processes and in some cases for different production machines. For satisfactory solution of this problem the rules are formulated on the base of laws, regulations and personal findings of the paper's authors in enterprises. In the paper occupational health and safety hazard rules in milling on these principles are formulated.

Keywords: Hazards, Occupational health and safety, Legislation, Milling

\section{References}

[1] MADLOVA, D., GEBHART, V. (2016). Occupational Health and Safety Hazards in Machining. Manufacturing Technology, Vol. 16, No. 4, pp. 744-749. ISSN 1213-2489.

[2] MADLOVA, D., GEBHART, V. (2015). Rizika bezpečnosti práce v podnicích. In: Proceedings of Riziko podnikových procesů, pp. 40 - 45. UJEP, Usti nad Labem. ISBN 978-80-7414-967-2

[3] CZ Labour code 262/2006 Sb.

[4] CZ law 309/2006 Sb.

[5] CZ law 372/2011 Sb.

[6] CZ law 251/2005 Sb.

[7] CZ government ordinance 432/2003 Sb.

[8] CZ government order 378/2001 Sb.

[9] CZ government order 495/2001 Sb.

[10] European occupational health and safety regulation EHS 89/391.

[11] EN ISO 13850 Safety of Machinery. Emergency stop.

[12] EN ISO 14119 Interlocking devices associated with guars.

[13] KOUBEK, J. (2007). Rizeni lidskych zdroju. 399 p., Management Press, Praha.

[14] http://www.suip.cz/_files/suip-b110a5cb403edcb12e206b5aebd1242/bezpecny_podnik_cj.pdf.

[15] VASILKO, K., MURCINKOVA, Z. (2014). Method of Immediately Cutting Process Stoppage. Manufacturing Technology, Vol. 14, No. 2, pp. 245-252. ISSN 1213-2489.

[16] STAVEK, M., ALES Z., LEGAT, V., TERINGEL, A. (2016). Operational Risk Management and Treatment at Technical Systems with Maintenance Support. Manufacturing Technology, Vol. 15, No. 3, pp. 429-435. ISSN $1213-2489$ 